\title{
Museum Study of Man and his Work
}

A

PAPER by Mr. de La Valette at a joint meeting of the Royal Society of Arts and the India Society on December 14, on the subject of Holland's colonial museums, raised the vital issue of the clash between the new tendency in science to co-ordinate its various branches devoted to the study of mankind and his works, and the old methods of museum arrangement which kept them severely apart.

This scientific humanism, as we may term it, though it is generally referred to as ethnography, covers much of the ground formerly divided up academically between the subjects of ethnology, anthropology, archæology, geography, history and art. It takes a group, racial or cultural, and studies it as a whole. In Holland, the makers of museums have adopted this point of view with enthusiasm, and have either altered drastically the old differently classified and over-crowded museums, or have built and endowed large new museums especially for the study and appreciation of the peoples and cultures of their overseas empire.

The Colonial Institute at Haarlem enables the Dutch people-students and ordinary citizens-to be initiated into the ancient civilizations embraced by their colonial possessions. Here man is not divorced from his inventions, his art and his accessories. He is shown, not as a 'laboratory specimen', but as a living human being whose racial features, geographic and climatic conditions and particular means of subsistence have forced him to live, dress, createboth in a religious and a material senso-in a manner peculiar to him. Films, lectures, photographs, booklets written by scholars and experts, fill out the picture and make the impact of new knowledge both sharper and deeper. The existence of this museum is almost entirely due to the acumen and enthusiastic enterprise of private individuals-bankers, colonial merchants, collectors and so forth.

Much the same policy is pursued by the Ethnographical Museum at Leyden, which is State supported and controlled by the University of Leyden. Here is an immensely rich collection of Indonesian religious art and textiles, but although æesthetic values are brought out so far as possible by architectural means, judicious lighting and dramatic placing, yet these exhibits - the apex of a culture-are shown in their relation to the whole. They are not chunks broken off, so to speak, and existing in a vacuum.

In Great Britain the story is very different. The Victorian passion for collecting and labelling specimens has given us magnificently large, wellstocked museums, the policy and arrangement of which are still the old ones of dry scholastic classifica. tion. Objects are related in kind and time, but are divorced entirely from the men who made and used them. The only exception to this rule is the India Museum, part of the Victoria and Albert massif, which, under its new curator, Mr. K. de B. Codrington, is endeavouring to pursue this modern policy of co-ordination of all aspects of a nation's (in this case, a sub-continent's) civilization. There is serious talk, however, of this forward-looking policy being abandoned, the collection broken up, and the objects scattered, according to their ethnological, artistic or historic interest, through the various institutes of South Kensington.

Mr. de La Valette ended his talk with a strong bid not only for the continued existence of the India Museum as an entity, but also for a larger, really comprehensive India Museum on the same lines, which would combine its own collection with that of Indian and Indian-influenced objects belonging to the British Museum. This suggestion was supported by Sir Robert Witt (chairman), Lord Amulree and Sir James McKenna, among others. Sir A. Ramaswami Mudaliar made a moving plea that his great country should be studied sympathetically, and that its ancient art and culture, and its present development, should in England have a setting worthy of the Indian Empire.

\section{Science in Radium Therapy}

$\mathrm{T}$ HE annual reports, which the Medical Research Council has now issued since 1923, enable the reader in retrospect to see how the methods of treatment of disease by means of radium have been evolved from frank experimentation to a procedure based on some, though limited, knowledge of the reactions of living tissues to radiation and supported by precision data on dosage.

The current report, No. 226 of the Special Report Series, "Medical Uses of Radium", is a summary of the work of the Council's research centres for 1936 (London: H.M. Stationery Office). The general scope of the experimental section, pp. 7-16, includes work of a purely physical and biological nature, that of the clinical section being largely concerned with the methods and results of treatment of malignant disease. A section on the treatment of simple metrorrhagia, pp. 37-38, is, however, not only of great clinical interest, but also affords a good example of the way in which a successful form of treatment has been evolved by the method of trial and error, with still no certainty as to the essential processes set into operation by radiation. As stated in the report, 837 cases have been under observation at the Marie Curie Hospital for from one to ten years, and of these 97 per cent of the menopausal cases and 78.5 per cent of the younger patients have remained well without further treatment. Yet there is no very definite evidence as to the relative importance of the actions of the rays upon (1) uterus and (2) ovary.

By reference to this and earlier reports, the reader can quickly see the chief methods in use in the treatment of cancer of the breast, uterus, mouth, nasopharynx, larynx, œsophagus and rectum. Not only so, but for each one of those sites there are statistical 
data giving the results of treatment, ranging in some cases over so much as fifteen years, and rarely so little as five. The data, taken in conjunction with those issued by the National Radium Commission, are in effect the answer to the question: What is the value of radium in the treatment of cancer? There are sites, such as the csophagus and rectum, where the data show that a permanent improvement in the condition is not as a rule to be expected. On the other hand, a patient exhibiting an early stage of the disease in cancer of the cervix uteri is after suitable radium treatment more likely than not to be free of the disease five to six years later.

Methods change, and the tendency for the last few years has been to avoid interstitial methods and replace them by the use of radium outside the body. Teleradium has been practised by several centres in Great Britain over a period of years, and an interesting account is given of the clinical uses of a one gram unit at the Middlesex Hospital.
Reference to the experimental section shows that researches essential to our understanding of the biological actions are being undertaken by several groups, notably at the Strangeways Laboratory at Cambridge, the Imperial College of Science and Technology, the Royal Cancer Hospital, the Mount Vernon Research Centre and at the Middlesex Hospital. As stated in the introduction, with leading principles being established, the make-shift ground of empiricism gives way to a surer basis of therapy. That basis is quickly becoming a scientific one, in the sense that doses of radiation are now prescribed and dispensed in a quantitative manner; this has been brought about only by long effort, an important step being the establishment of the rontgen as an X-ray unit. The Medical Research Council, systematically and over a course of years, has aided the work of the British $\mathrm{X}$-ray Unit Committee, which had much to do with fixing the value of the unit now in general use.

\section{Cultural Successions in British Archæology}

$\mathrm{B}$ RITISH archæology, perhaps, has profited more than any other field of archæological investigation by the recent diversion of interest from the more striking products of a culture to the building up of a culture complex as a whole. By this means it is now becoming possible to trace in greater detail and with more certainty the racial and cultural successions in Britain, and their interrelations, which went to make up the composite product appearing in these islands on the threshold of historic times. Hence the importance of such sites as Maiden Castle, St. Albans and Wheathampstead, on which more or less continuous or contiguous occupation over a comparatively long period affords an opportunity to follow the changes and modifications brought about by successive cultures.

These great sites, however, are exceptional ; but an analogous opportunity, if on a somewhat lesser scale, is afforded for northern England by Eddisbury Hill, the Cheshire hill-fort, of which the recent excavation was described by Mr. W. J. Varley before the Ancient Monuments Society of Manchester on December 6. Here no less than six distinct cultural periods have been observed in the earthwork defences on the crest of the hill. A period of open occupation at the very close of the Bronze Age is represented by burial urns. This was followed by an immigration from the south, which was responsible for the largest hill-fort known in the north of England. An elaborate system of ramparts, ditches and entrances was built up during the first century B.c. This was still further enlarged under the threat of invasion by the Romans. This defensive system exceeds in complexity that of any other known Iron Age hill-fort in Britain. During the Roman occupation the rampart was dismantled and the ditches filled in. The hill lost its defensive character ; and in late Roman times there is evidence of the floors of an open site occupation. The last cultural phase is early Saxon, of which relics have been discovered in a hut built over a filled-in ditch between two ramparts. Of traces of the Danish invasion none has hitherto been found; but excavation is not yet complete.

Another instance of a succession of occupations comes from Welwyn. which is all the more significant in that it lies within the sphere of influence of the Belgic culture, which Dr. R. E. Mortimer Wheeler has described in the St. Albans area. The exploration of the Roman villa which was discovered by accident at Welwyn some five years ago points to the probability that this was a Roman farm; but further investigation shows that it had been preceded by a British, or rather a Belgic, farm.

As was pointed out by $\mathrm{Mr}$. J. Ward Perkins, the excavator, in describing the site before the Society of Antiquaries on December 9, this is the first proved instance of the conversion of a preRoman into a Roman farm, although it would not be unreasonable to presume that this had happened with some frequency. The site is also notable for affording the rare evidence of a tower forming part of the Roman building. Such a tower might be presumed to be of frequent occurrence in Roman Britain, although actual traces of an upper story have not often been found. Here the lower part of the tower had walls of flint and brick, with coloured wall-plaster, while the upper part was of timber framing, probably filled with pisé-de-terre.

The result of the excavation at Welwyn is especially instructive from more than one point of view. The discovery of a pre-Roman agricultural occupation of the site links up with a number of discoveries of recent years bearing on the social and economic life of the period preceding the Roman invasion. That such discoveries have been made is to be traced in no small part to the efforts and influence of a research committee of the British Association, which directed attention to the significance of apparently unimportant and irrelevant finds on sites in Roman Britain by granting a small subsidy for many years to excavations on such sites in return for reports on the pre-Roman finds, which previously had been neglected. The growth from these small beginnings vindicates the prescience of those by whom the committee was instituted.

Further, and in the same connexion, the Welwyn excavation illustrates the advantages which may accrue from investigating the small and superficially unimportant site. 